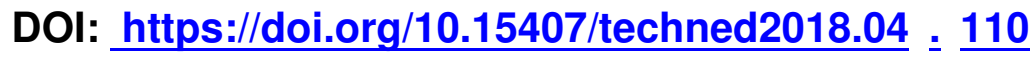

\title{
THE DEVELOPMENT OF SMART SYSTEMS FOR CONTROL, METERING AND ENERGY MANAGEMENT IN LIBERALIZED ELECTRICITY MARKET OF UKRAINE
}

$\quad$ Journal
Publisher
ISSN
Issue
Pages

Tekhnichna elektrodynamika Institute of Electrodynamics National Academy of Science of Ukraine 1607-7970 (print), 2218-1903 (online) No 4, 2018 (July/August)

$110-117$

\section{Author \\ O. Kotsar}

National Technical University of Ukraine "Igor Sikorsky Kyiv Polytechnic Institute", pr. Peremohy, 37, Kyiv, 03056, Ukraine, e-mail: kovpers@ukr.net

\section{Abstract}

The period of the emergence of the Ukrainian electricity market was characterized, in particular, by the large-scale implementation of automated systems of commercial electricity metering (ASCEM) of the wholesale and retail markets players in order to form the information support of the payments for electricity. The creation of ASCEM in the wholesale market was actually 
completed in 2010, and since March 2011 the payments in the Wholesale Electricity Market (WEM) of Ukraine are based on ASCEM data of the WEM players. The ASCEM in the retail electricity market is mainly implemented by industrial consumers. Such important areas of electricity consumption as the householders and utilities are practically not covered by ASCEM today, first of all, due to the lack of appropriate normative support. Implemented of the ASCEM on the industrial enterprises today practically are not used for payments (except for the power supply at unregulated tariff), and are used mainly for control the power consumption modes. In the general case, the information interaction of the ASCEM of wholesale and retail markets players is impossible due to the lack of compatibility, in particular information, resulting from the creation of ASCEM on the basis of various regulatory requirements. All this is a barrier for the full-scale use of ASCEM in conditions of Ukrainian electricity market liberalization, where every consumer, including the household, is a potential player in the electricity market. The article analyzes the current state and identifies the ways of development ASCEM in order to increase the efficiency of their application in conditions of Ukrainian electricity market liberalization. The experience of EU member states in the Smart Metering Systems roll-out is being studied in order to create information support of commercial metering and tasks of energy usage management in the conditions of liberalized electricity markets functioning. References 9 , table 1.

Key words: ASCEM, data metering, electricity, meter, metering, electricity market, Smart Grid, Smart Meter, Smart Metering System.

Received: 07.09 .2017

Accepted: 16.02.2018

Published:

\section{References}


1. On Electricity Market: The Law of Ukrainel 13.04.2017 No. 2019-VIII.

URL: http://zakon3.rada.gov.ua/laws/show/2019-19 (accessed at 20.08.2017). (Ukr)

2. Directive 2009/72/EU OF THE EUROPEAN PARLIAMENT AND OF THE COUNCIL of

13.07.2009 concerning common rules for the internal market in electricity and repealing Directive 2003/54/EC. Official Journal of the European Union. 2009. No 8. L211/55-93.

3. Instruction on the Procedure of Commercial Metering of Electric Energy. Annex 10 to the Agreement between the Members of the Wholesale Electricity Market. Approved by Council of the Wholesale Electricity Market of Ukraine, the protocol from June 9, 1998. No 8 (with amendments and supplements). (Ukr)

4. Rules of Electric Energy Usage. Approved by Resolution of NERC from July 31, 1996, No 28 in the wording of the Resolution of NERC from October 17, 2005, No 910 (with amendments and supplements. (Ukr)

5. Program of the Successive Implementation of the ASCEM in Wholesale Electricity Market of Ukraine (second edition). Approved by Council of the Wholesale Electricity Market of Ukraine, the protocol from November 25, 2005. No 12. (Ukr)

6. General Technical Requirements for the Automated Commercial Metering System for the Wholesale Electricity Market of Ukraine. Part I. System for Electric Energy Commercial Metering Data Collecting, Processing and Exchange in the Wholesale market. Annex 7.4 to the Agreement between the Members of Wholesale Electricity Market of Ukraine. Approved by Council of the Wholesale Electricity Market of Ukraine, the protocol from January 9, 2003. No 7 (with amendments and supplements). (Ukr)

7. General Technical Requirements for the Automated Commercial Metering System for the Wholesale Electricity Market of Ukraine. Part II. The Exact Time System and Synchronous Measurement Subsystem of the Automated Commercial Metering System for the Wholesale Electricity Market of Ukraine. Annex 7.4 to the Agreement between the Members of the Wholesale Electricity Market. Approved by Council of the Wholesale Electricity Market of Ukraine, the protocol from September 24, 2004. No 12. (Ukr)

8. Commission Recommendation 2012/148/EU of 9 March 2012 on preparations for the roll-out of smart metering systems. Official Journal of the European Union. 2012. No 3. L73/9-22.

9. Smart Metering Systems in EU Member States. Final report. Prepared for Directorate General for Energy, Directorate B - Internal Energy Market, by ICCS-NTUA, Athens, AF Mercados EMI, Madrid, 25 June 2015. 147 p. 